\title{
GEOMETRY OF CORONAL MASS EJECTIONS IN THE CONTEXT OF RECENT SOLAR CYCLE
}

\author{
Rajesh K. Mishra ${ }^{1}$ and Rekha Agarwal ${ }^{2}$ \\ ${ }^{1}$ Computer and I.T. Section, Tropical Forest Research Institute, \\ P.O.: RFRC, Mandla Road, Jabalpur (M.P.) 482 021, INDIA \\ ${ }^{2}$ Department of Physics, Govt. Model Science College (Autonomous), \\ Jabalpur (M.P.) 482 001, INDIA \\ e-mail: rkm_30@yahoo.com or rm_jbp@yahoo.co.in
}

\begin{abstract}
Coronal mass ejections (CMEs) disrupt the flow of the solar wind and produce disturbances that strike the Earth with sometimes catastrophic results. These ejections are often associated with solar flares and prominence eruptions, but they can also occur in the absence of either of these processes. The frequency of CMEs varies with the sunspot cycle. At the solar minimum we observed about one CME a week. Near the solar maximum we could observe an average of 2 to 3 CMEs per day. We have studied different CME characteristics based on the observation with Large Angle and Spectrometric Coronagraph (LASCO) on board of the Solar and Heliospheric Observatory (SOHO) space craft during the period 1996-2006. It is noteworthy that the rate of occurrence of class B CMEs (with the measurement position angle (MPA) in the range $200^{\circ}-360^{\circ}$ ) is greater than that for class A CMEs (the MPA in the range $50^{\circ}-200^{\circ}$ ). The CME occurrence spectrum for both classes follows the trend of the phase of solar cycle, and the maximum number of both type CMEs seems to occur during the maximum solar activity. It is also observed that the maximum numbers of class A, class B CMEs are in a speed range of $0-500 \mathrm{~km} / \mathrm{s}$. We have observed that the maximum number of class A, class B CMEs occurred in the apparent angular width range $0^{\circ}-90^{\circ}$. It is also found that the maximum numbers of class $\mathrm{A}$ and class $\mathrm{B}$ CMEs occur when the position angle ranges in $5^{\circ}-100^{\circ}$ and $250^{\circ}-300^{\circ}$ respectively.

Key words: coronal mass ejections, position angle, solar cycle, geomagnetic storm.
\end{abstract}

\section{INTRODUCTION}

The coronal mass ejections (CMEs) are large-scale magnetized plasma structures that erupt from the Sun and are transported in the heliosphere [1]. They are found to correlate with the occurrence of strong non-recurrent disturbances in the interplanetary medium, and their interactions with Earth's magnetosphere cause severe geomagnetic storms [2,3]. CMEs typically appear as loop-like features that disrupt the helmet streamers in the solar corona. These coronal mass ejections carry a bulk of solar material in the range $10^{11}-10^{14} \mathrm{~kg}$ at the speeds of $10-4000 \mathrm{~km} / \mathrm{s}$. The Large Angle and Spectrometric Coronagraph (polarimeter) (LASCO) on board the Solar and Heliospheric Observatory (SOHO) space craft (the solar maximum mission (SMM)) allowed identification of many properties of CMEs [4]. The huge amount of energy involved in such electronic processes is to be stored in the magnetic fields surrounding the mass ejection site. The mentioned SOHO space craft has by now extensively observed the CME events since the solar minimum in 
1996 up to the current solar cycle. Some of the SOHO/LASCO observations have been described by many workers [5-8]

Recently, many authors have investigated the CME speeds at the near-Sun region, mainly from the space-borne white light images and their implications at $1 \mathrm{AU}$ [9-11]. In the present work, various properties of coronal mass ejections have been classified according to their source region (based on the measurements of position angle) and discussed.

\section{OBSERVATION DATA AND THEIR ANALYSIS}

Our knowledge about the coronal mass ejection comes from two spatial domains: the near-Sun (up to 30 solar radii) region remotely sensed by a coronagraph; and the geospace (and beyond) where in situ observations are made by a space craft. In the present study, we have analyzed in detail all coronal mass ejections occurred from 1996 to Apr. 2006 based on the data from (http://cdaw.gsfc.nasa.gov/CME list). We have used a new aspect to identify the properties of coronal mass ejections, and classified CMEs into two classes with respect to their position angle, namely, class A and class B. Class A CMEs are those which occur with the measurement position angle (MPA) in the range $50^{\circ}-$ $200^{\circ}$ and class B CMEs - with MPA in the range $200^{\circ}-360^{\circ}$.

\section{RESULTS AND DISCUSSION}

Up to date, we have identified 5235 CMEs which occurred in the MPA range $0^{\circ}-200^{\circ}$, and 5159 CMEs which occurred in the MPA range $200^{\circ}-360^{\circ}$ during the period from Jan. 1996 to Apr. 2006. The number of class A CMEs is 5032 (in the MPA range $50^{\circ}-200^{\circ}$ ). We have identified 9, 22, 64, 93, 120, 111, 104, 64, 40, 30 sunspots during the years 1996, 1997, 1998, 1999, 2000, 2001, $2002,2003,2004,2005$ respectively. The histogram of two classes of CME is depicted in Fig. 1. Empty and black-shaded histograms stand for class A and B, respectively. It is apparent from Fig. 1 that the occurrence rate of class B CMEs was greater than that for class A in 1996, which was the year of the minimum solar activity. It is also observable from Fig. 1 that the maximum number of both types of CME occurred in year 2000, but the occurrence rate of class B CME is greater in comparison with class A [12]. Thus, we conclude that the maximum number of both type CMEs occurred during the maximum activity of solar cycle. The CME speed is determined when at least two height measurements are available. Sometimes, data gaps happen, due to our inability to measure the speeds of about $3 \%$ of the CMEs.

We have taken the linear speed of CMEs in $\mathrm{km} / \mathrm{s}$. The number of events in both classes is almost the same in each speed distribution range as depicted in Fig. 2, where empty and black-shaded histogram denotes A and B class CMEs, respectively. Further, it was observed that the maximum number of CMEs of classes A and B occurred in the range of $0-500 \mathrm{~km} / \mathrm{s}$. The histograms of position angle of class A and class B CMEs are plotted in Fig. 3. We have found that the maximum number of $\mathrm{B}$ class CMEs occurred in the range $250^{\circ}-300^{\circ}$, whereas the minimum number of class $\mathrm{B} C \mathrm{CMEs}$ occurred in the range $300^{\circ}-360^{\circ}$. In the case of class $A$ the maximum number of CMEs occurred in the range $50^{\circ}-100^{\circ}$ and the minimum number - in the range $(0-50)^{\circ}$. This result is similar to the earlier 
findings [13]. Figure 4 shows the distribution of the apparent angular width of class A and class B from Jan. 1996 to Apr. 2006. In Fig. 4 empty and black-shaded histogram indicates Class A and B CMEs, respectively. In order to investigate the properties of CMEs using the angular width data, we grouped the CMEs into four populations: $(0-90)^{\circ},(90-180)^{\circ},(180-270)^{\circ}$ and $(270-360)^{\circ}$. It is observed that in the width distribution the maximum number of CMEs occurred in the range $(0$ $90)^{\mathrm{o}}$ in both classes. It is also observed that in the angular width distribution the minimum number of CMEs occurred in the range $180^{\circ}-270^{\circ}$ in both classes.

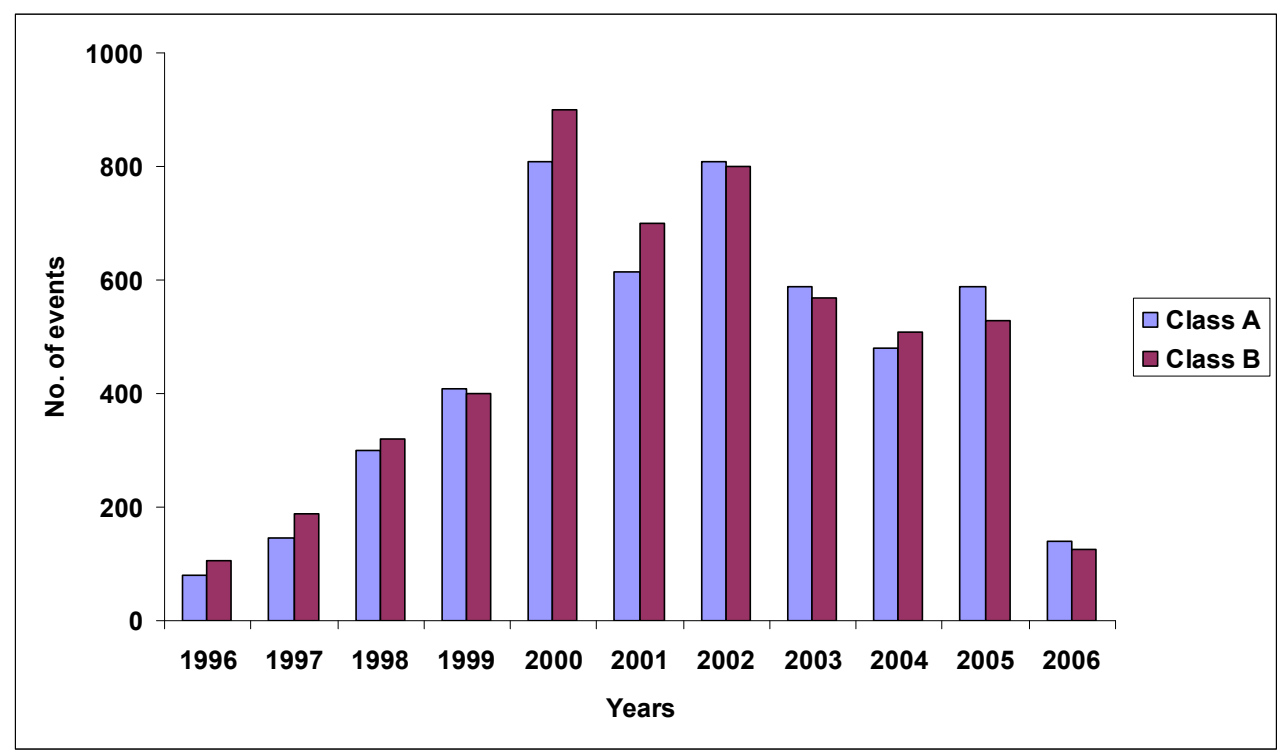

Fig. 1. Variation of CMEs during the years 1996-2006.

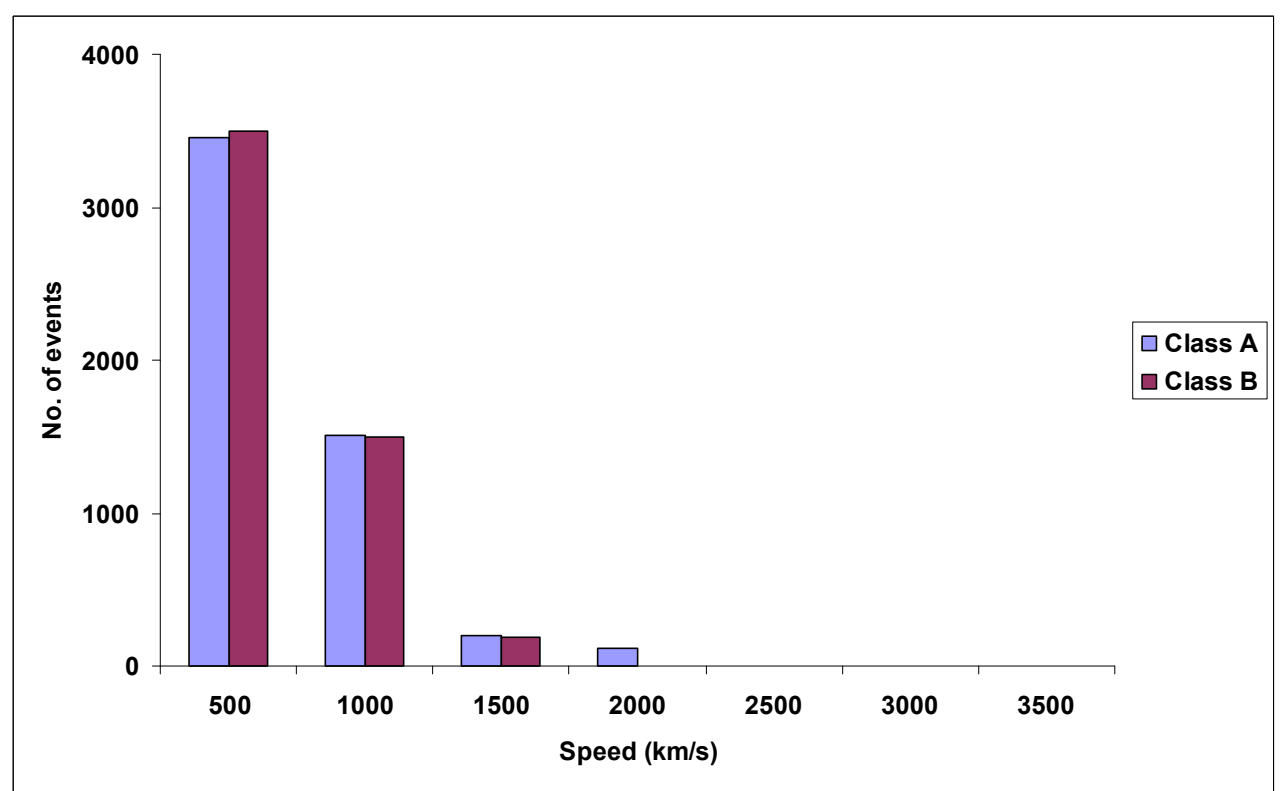

Fig. 2. Histogram of the SME speed distribution. 


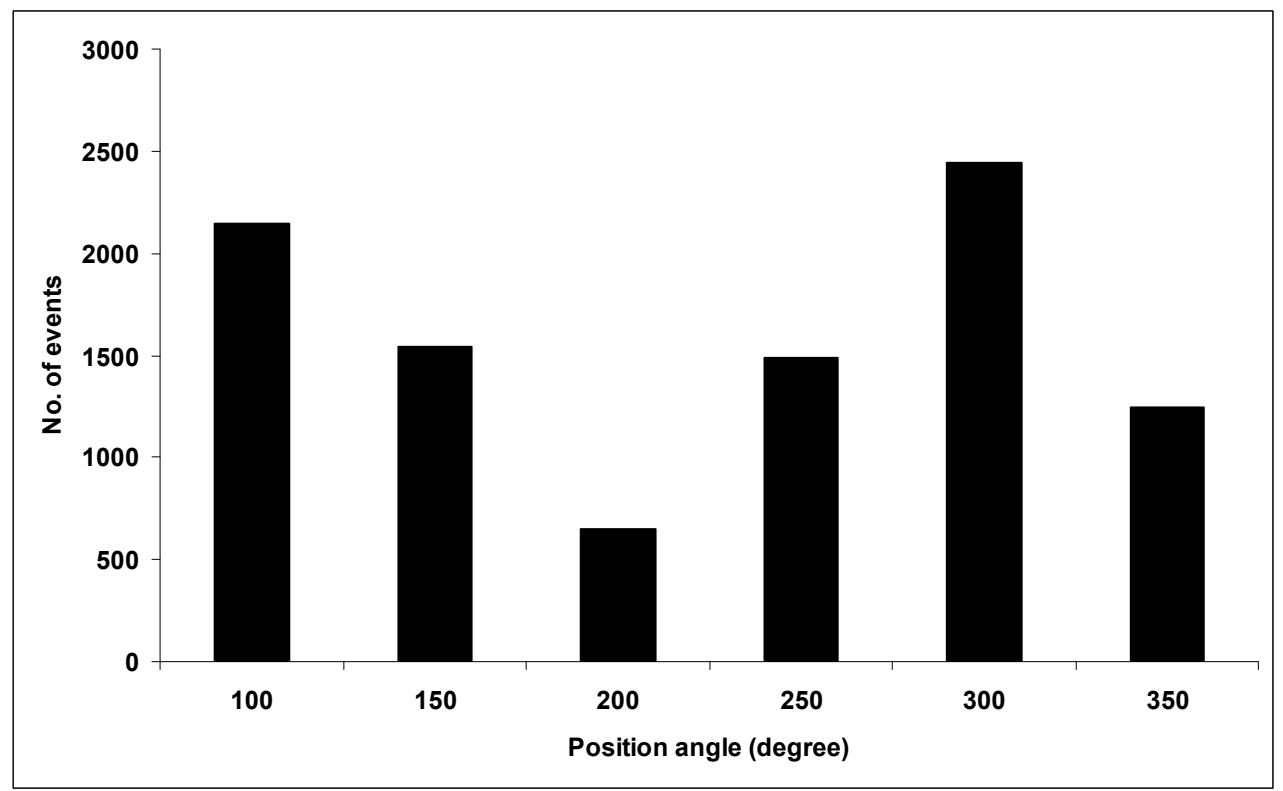

Fig. 3. Histogram of the SME position angle distribution.

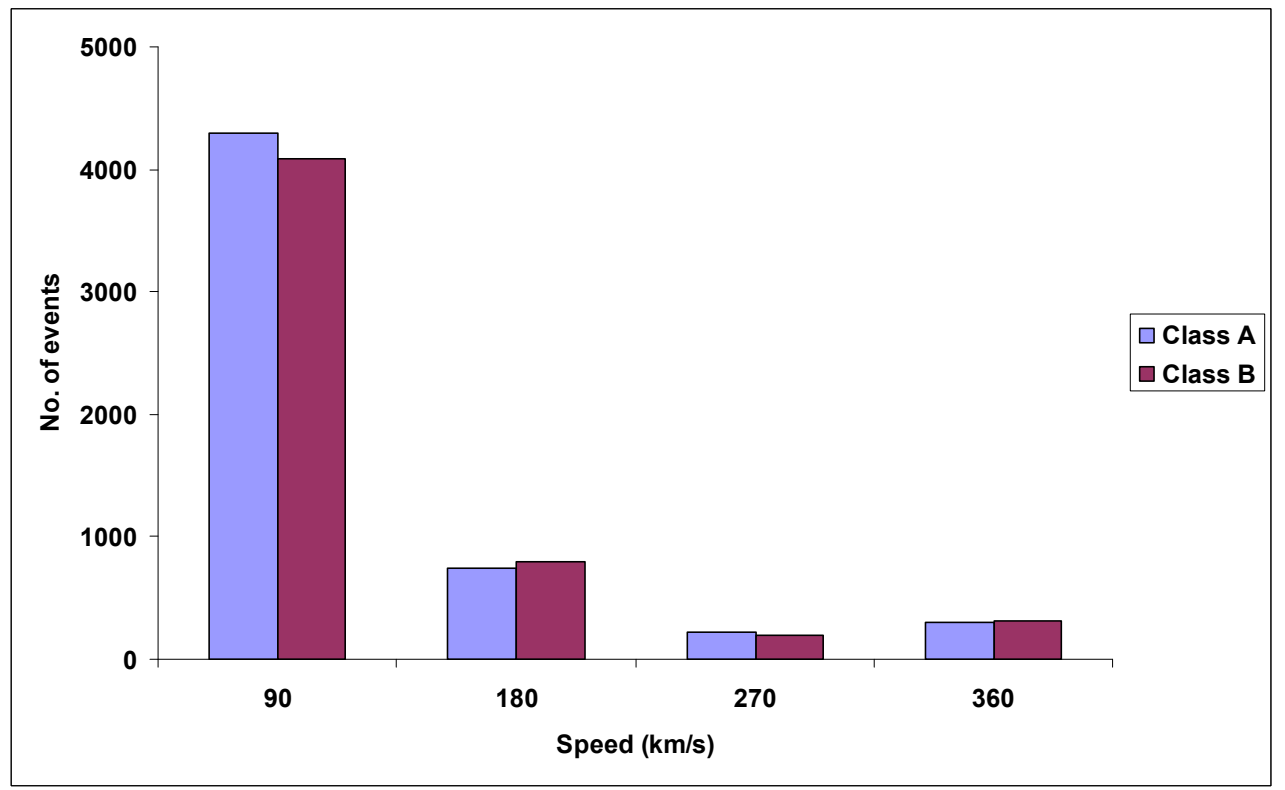

Fig. 4. Histogram of the SME apparent angular width distribution.

\section{CONCLUSIONS} drawn:

Based on the present investigations, the following conclusions have been

- The occurrence of both classes of coronal mass ejections follows the phase of solar cycle. Majority of A and B class CMEs have occurred during the maximum activity period of solar cycle.

- The majority of class A and B CMEs have occurred in the measurement position angle ranges from $50^{\circ}-100^{\circ}$ to $200^{\circ}-250^{\circ}$, respectively. 
- The maximum number of class A and B CMEs have occurred in the speed range $0-500 \mathrm{~km} / \mathrm{s}$.

- The maximum number of class A and B CMEs have occurred in the apparent angular width range $(0-90)^{\circ}$.

\title{
ACKNOWLEDGEMENTS
}

The authors are indebted to various experimental groups, in particular, Prof. Margret D. Wilson, Prof. K. Nagashima, Miss. Aoi Inoue and Prof. J.H. King for providing the data. The SOHO/LASCO data used here are produced by a consortium of the Naval Research Laboratory (USA), Max-Planck-Institut fur Astronomie (Germany)), Laboratoire d'Astronomie (France), and the University of Birmingham (UK). SOHO is a project of international cooperation between ESA and NASA.

\section{REFERENCES}

1. Tousey, R. (1973). The solar corona space res., 13, 713.

2. Gosling, J.T. (1993). Phys. Fluids, 5, 2639.

3. Webb, D.F. (1995). Rev. Geophys. Suppl., 33, 577.

4. Mac Queen, R.M. et. al. (1980). Sol. Phys., 65, 91.

5. Gopalswamy, et. al. (2003). Astrophys. J., 598, 63.

6. St. Cyr. et. al. (2000). J. Geophys. Res., 105, 18169.

7. Howard, R .A., et. al. (1997). Geophys. Monograph, 99, 17.

8. Gopalswamy, et. al. (2004). J. Geophys. Res. 109, A 12105.

9. Shrivastava, N., \& Venkatakrishnan, P. (2002). Geophys. Res. Lett., 29 (9), 1287.

10. Cane, H.V, Richardson, I.G., \& St. Cyr., O.C. (2000). Geophys. Res. Lett., 27, 3591.

11. Zhang, J., Dere, K.P., Howard, R.A., \& Bothmer, V. (2003). Astrophys. J., 582, 520.

12. Yashiro, et. al. (2004). Adv. Space Res., 32, 2631.

13. Hundhausen, et. al. (1993). J. Geophys. Res., 98, 113177.

\section{KORONĀLO MASU IZVIRDUMU (KMI) GEOMETRIJA PĒDĒJO SAULES CIKLU KONTEKSTĀ}

\author{
R.K. Mishra, R. Agarwal \\ Kopsavilkums
}

Koronālie masas izvirdumi (KMI) sagrauj Saules vēja plūsmu un noved pie perturbācijam, kas var radīt uz Zemes spēcīgas katastrofas. KMI frekvence mainās atkarībā no saules plankumu cikla. Pie minimālās saules aktivitātes mēs novērojām vienu KMI dienā, bet tuvu maksimālai Saules aktivitātei - 2-3 KMI dienā. Mēs pētijāām dažādus raksturlielumus, kas iegūti novērojumos uz Saules ar platleṇķa korongrafa spektrometru (LASCO) no heliosfēriskās observatorijas (SOHO) kosmosa kug̣a borta laika periodā no 1996. gada līdz 2006. gadam. Iegūts rezultāts, ka KMI klases B rašanās frekvence (pie mērỉjuma leņ̧̧a diapazonā $200^{\circ}$ līdz $300^{\circ}$ ), lielāka nekā KMI klasei A $\left(50^{\circ}-200^{\circ}\right)$. KMI rašanās spektrs abām klasēm atbilst Saules ciklu tendencēm; maksimālais abu tipu KMI skaits ir pie Saules maksimālās aktivitātes.

01.05.2009. 